(compare Figs. 2A and 3). Nevertheless, in both environments there was no relation between ability to diversify and time spent evolving in the original high-nutrient media (Fig. 3) (sign tests of correlations between number of genotypes and transfer number for the six lines: $P>0.2$ in both cases).

Adaptation can limit the ability of bacterial genotypes to diversify genetically. This was not the result of generalist evolution or the evolution of an intrinsic reduction in evolvability, but was caused by environment-specific adaptation. Given the strong empirical support for both the importance of environmental heterogeneity in diversification (7-14) and epistasis $(6,24)$, it is likely that rugged fitness landscapes, a requirement for the observed effects, are common. These results are therefore likely to be generally relevant and may help to explain patterns of diversity over both micro- and macroevolutionary time scales. Consistent with recent interpretations of macroevolutionary adaptive radiations (25), we predict that in environments that can potentially support similar levels of diversity, diversification is more likely to occur immediately following colonization of the environment than through expansion into new niches within the environment after an extinction event.

References and Notes

1. H. Levene, Am. Nat. 87, 331 (1953).

2. P. W. Hedrick, M. E. Ginevan, E. P. Ewing, Annu. Rev. Ecol. Syst. 7, 1 (1976).

3. P. W. Hedrick, Annu. Rev. Ecol. Syst. 17, 535 (1986).

4. T. Dobzhansky, Genetics and the Origin of Species (Columbia Univ. Press, New York, 1937).

5. M. C. Whitlock, P. C. Phillips, F. B. G. Moore, S. J. Tonsor, Annu. Rev. Ecol. Syst. 26, 601 (1995).

6. M. J. Wade, in Epistasis and the Evolutionary Process, J. B. Wolf, E. D. Brodie, M. J. Wade, Eds. (Oxford Univ. Press, Oxford, 2000), pp. 213-231.

7. R. Korona, C. H. Nakatsu, L. J. Forney, R. E. Lenski, Proc. Natl. Acad. Sci. U.S.A. 91, 9037 (1994).

8. P. B. Rainey, M. Travisano, Nature 394, 69 (1998).

9. D. E. Rozen, R. E. Lenski, Am. Nat. 155, 24 (2000).

10. A. Buckling, P. B. Rainey, Nature 420, 496 (2002).

11. D. Schluter, Am. Nat. 157 (suppl.), S4 (2000).

12. S. M. Vamosi, D. Schluter, Proc. R. Soc. London Ser. B 269, 923 (2002).

13. R. F. Rosenzweig, R. R. Sharp, D. S. Treves, J. Adams, Genetics 137, 903 (1994).

14. R. Kassen, J. Evol. Biol. 15, 173 (2002).

15. S. Wright, Genetics 16, 97 (1931).

16. H. J. Muller, Biol. Rev. Camb. Philos. Soc. 14, 261 (1939).

17. A. Buckling, R. Kassen, G. Bell, P. B. Rainey, Nature 408, 961. (2000).

18. F. J. Ayala, C. A. Campbell, Annu. Rev. Ecol. Syst. 5, 115 (1974).

19. M. L. Rosenzweig, Species Diversity in Space and Time (Cambridge Univ. Press, Cambridge, 1995).

20. P. B. Rainey, M. J. Bailey, Mol. Microbiol. 19, 521 (1996).

21. R. Kassen, A. Buckling, G. Bell, P. B. Rainey, Nature 406, 508 (2000).

22. Materials and methods are available as supporting material on Science Online.

23. G. Bell, Selection: The Mechanism of Evolution (Chapman \& Hall, London, 1997).

24. A. R. Templeton, in Epistasis and the Evolutionary Process, J. B. Wolf, E. D. Brodie, M. J. Wade, Eds. (Oxford Univ. Press, Oxford, 2000).
25. D. Schluter, The Ecology of Adaptive Radiations (Oxford Univ. Press, Oxford, 2000).

26. We thank L. Hurst and three anonymous referees for comments on the manuscript. This work was funded by the Royal Society and Natural Environment Research Council (UK).
Supporting Online Material

www.sciencemag.org/cgi/content/full/302/5653/2107/DC1

Materials and Methods

References

7 July 2003; accepted 14 October 2003

\title{
Melt Inclusions in Veins: Linking Magmas and Porphyry Cu Deposits
}

\author{
Anthony C. Harris, ${ }^{1 *}$ Vadim S. Kamenetsky, ${ }^{1}$ Noel C. White, ${ }^{1}$ \\ Esmé van Achterbergh, ${ }^{2}$ Chris G. Ryan ${ }^{2}$
}

\begin{abstract}
At a porphyry copper-gold deposit in Bajo de la Alumbrera, Argentina, silicatemelt inclusions coexist with hypersaline liquid- and vapor-rich inclusions in the earliest magmatic-hydrothermal quartz veins. Copper concentrations of the hypersaline liquid and vapor inclusions reached maxima of 10.0 weight \% (wt $\%)$ and $4.5 \mathrm{wt} \%$, respectively. These unusually copper-rich inclusions are considered to be the most primitive ore fluid found thus far. Their preservation with coexisting melt allows for the direct quantification of important oreforming processes, including determination of bulk partition coefficients of metals from magma into ore-forming magmatic volatile phases.
\end{abstract}

In porphyry ore deposits, metals are concentrated by large volumes of magmatic volatiles exsolved from crystallizing upper crustal magma bodies (1). Whether an ore deposit forms depends on the availability of metals in the magma, the partitioning of those metals into the volatile phase, and the history of the fluid after release from the magma (2-4). Ores are typically associated with hydrothermal mineral assemblages produced by the interaction of magmatic fluids with wall rocks (5). The earliest formed hydrothermal alteration of wall rocks is potassic (biotite-K-feldspar-quartz with or without magnetite assemblage) and is caused by high temperature $\left(350^{\circ}\right.$ to $800^{\circ} \mathrm{C}$ ) and saline (up to 70 weight \% equivalent $\mathrm{NaCl}$ ) fluids $(6,7)$. Discovery of silicate-melt inclusions coexisting with fluid inclusions in magmatic-hydrothermal quartz veins unambiguously links devolatilization of the magma with the associated porphyry ore deposit. This occurrence preserves the most primitive magmatic volatiles and the melt from which these were derived and, with the use of advanced microanalysis techniques, allows chemical changes to be traced through the evolution of the hydrothermal system. Moreover, we are able to use those data to quantify the magmatic-hydrothermal processes that lead to the formation of porphyry $\mathrm{Cu}$ deposits.

${ }^{1}$ Centre for Ore Deposit Research, University of Tasmania, Private Bag 79, Hobart, Tasmania 7001, Australia. ${ }^{2}$ Commonwealth Scientific and Industrial Research Organization Exploration and Mining, Post Office Box 136, North Ryde, New South Wales 1670, Australia.

*To whom correspondence should be addressed. Email: A.Harris@utas.edu.au
Bajo de la Alumbrera is an Au-rich porphyry $\mathrm{Cu}$ deposit where potassic alteration assemblages overprint several phases of porphyritic dacite intrusions and are associated with the bulk of the disseminated $\mathrm{Cu}-\mathrm{Fe}$ sulfides and $\mathrm{Au}$. High temperature (maximum of $750^{\circ} \mathrm{C}$ ) and saline fluid ( $>35$ wt \% equivalent $\mathrm{NaCl}$ ) of magmatic origin (as inferred from the calculated $\delta^{18} \mathrm{O}$ and $\delta \mathrm{D}$ compositions) formed these alteration assemblages (8). Some of the earliest $\mathrm{Cu}$-Fe sulfides occur in diffuse quartz veins, which are texturally similar to those described as A veins (9); however, the presence of silicate-melt inclusions warrants a new vein subclass. Hereafter we refer to them as $\mathrm{P}$ veins, reflecting their primitive role in the evolution of the magmatic-hydrothermal system. Typically, they consist of sugary quartz, with lesser amounts of K-feldspar and with or without hornblende-biotite-magnetite-chalcopyrite $\left(\mathrm{CuFeS}_{2}\right)$ and pyrite.

The $\mathrm{P}$ veins contain silicate-melt inclusions that consist of silicate crystals, vapor bubbles, salt crystals, and opaque oxide and sulfide crystals (Fig. 1). These inclusions are similar to those in magmatic quartz phenocrysts in the mineralized intrusions (10). Heating experiments (11) on silicate-melt inclusions revealed consistent phase transformations: The dissolution of the salt phases (e.g., halite and sylvite) occurs between $105^{\circ}$ and $560^{\circ} \mathrm{C}$; dissolution of crystalline silicate phases occurs between $650^{\circ}$ and $765^{\circ} \mathrm{C}$. After heating the host quartz crystals to $800^{\circ} \mathrm{C}$ at 1 atm external pressure for several hours, the sample was quenched to produce a silicate glass, which is extremely rich in $\mathrm{K}_{2} \mathrm{O}$ compared to whole rock analyses and has a composition similar to K-feldspar (table S2). This composition may represent a chemically modified melt trapped in a dominantly aqueous environment or may contain ex- 
cess K-feldspar trapped with the evolved melt.

Remelted silicate-melt inclusions are not homogeneous but contain small ( $<1$ to $8 \mu \mathrm{m})$ globules crowded with salt crystals, a vapor bubble $(0.5$ to $4 \mu \mathrm{m})$, and aqueous liquid (Fig. 2 and fig. S1). These inclusions represent the original entrapment of a two-phase system, i.e., melt and aqueous fluid. The inability to homogenize or remix the hypersaline fluid phase into the silicate melt, even after heating to high temperatures (up to $1000^{\circ} \mathrm{C}$ ) or for extended periods (60 hours at $850^{\circ} \mathrm{C}$ ), confirms that these silicate-melt inclusions represent heterogeneous trapping of phases immiscible at magmatic or near-magmatic conditions (12). Nondestructive in situ analysis by nuclear microprobe (protoninduced x-ray emission, or PIXE) was used to image the element distribution in heated silicate-melt inclusions (11). The data indicate that the highest concentrations of $\mathrm{Cu}$ and $\mathrm{Fe}$ reside in the Cl-rich fluid phase (Fig. 2 and fig. S2), consistent with the preferential partitioning of metals into the brine over the silicate melt from which these fluid phases were exsolved $(13,14)$.
Fluid inclusions spatially associated with silicate-melt inclusions in the $\mathrm{P}$ veins at Bajo de la Alumbrera are divided into two groups: group 1, vapor-rich and polyphase hypersaline liquid-rich inclusions, and group 2, liquid-rich brine with few vapor-rich inclusions (Fig. 1). Fluid inclusions of group 1 coexist with silicate-melt inclusions in primary inclusion clusters interpreted to have been trapped during formation of the $\mathrm{P}$ veins. Group 2 inclusions occur in secondary trails that cut quartz and are related to later fracturing; therefore, these later inclusions preserve lower temperature and chemically evolved fluid.

Heating experiments (11) on primary group 1 hypersaline liquid inclusions revealed phase transformations that are similar to those observed in brine globules in the spatially and temporally associated silicate-melt inclusions. Final salt dissolution occurs between $480^{\circ}$ and $540^{\circ} \mathrm{C}$; complete homogenization of these fluid inclusions by vapor disappearance occurs from $745^{\circ} \mathrm{C}$ up to $845^{\circ} \mathrm{C}$. The calculated salinities of the inclusions are up to $62 \mathrm{wt} \%$ equivalent $\mathrm{NaCl}$, implying a magmatic origin, consistent with their temperature (7). No microthermom-

\begin{tabular}{|l|l|}
\hline \multicolumn{1}{|c|}{ Type \& Description } \\
\hline $\begin{array}{l}\text { Silicate-melt inclusions with brine globules: } \\
\text { Silicate crystals - vapor (20-40 volume \%) } \pm \text { salt(s)- } \\
\text { chalcopyrite - magnetite. Size varies between } 5 \text { and } \\
25 \mu \mathrm{m} \text {, up to } 45 \mu \mathrm{m} \text {. Occur as negative crystals or are } \\
\text { spherical. Minor amounts of liquid associated with } \\
\text { halite (?sylvite) crystals. }\end{array}$ \\
$\begin{array}{l}\text { Vapor-rich fluid inclusions: } \\
\text { Vapor - chalcopyrite } \pm \text { liquid (<10 volume \%). } \\
\text { Elongate ellipsoidal inclusions or negative crystal } \\
\text { shapes (5-35 } \mu \mathrm{m}) .\end{array}$ \\
\hline $\begin{array}{l}\text { Polyphase hypersaline fluid inclusions: } \\
\text { Salts (halite-sylvite) - anhydrite - vapor - liquid } \pm \text { chal- } \\
\text { copyrite - magnetite (hematite). Biotite, hornblende, } \\
\text { apatite, and rutile also occur. There are several other } \\
\text { as yet unidentified opaque phases. Elongate ellipsoi- } \\
\text { dal inclusions or negative crystal shapes (5-40 } \mu \mathrm{m}) .\end{array}$ \\
\hline $\begin{array}{l}\text { Brine fluid inclusions: } \\
\text { Halite - liquid - vapor (<20 volume \%) } \pm \text { chalcopyrite. } \\
\text { Negative crystal shapes (<35 } \mu \mathrm{m}) .\end{array}$
\end{tabular}

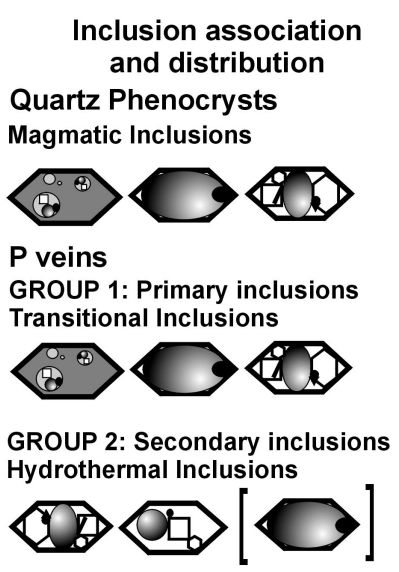

Fig. 1. Definition of inclusion populations observed in quartz from porphyritic intrusions at Bajo de la Alumbrera [modified after Ulrich et al. (8)]. Silicate-melt (gray hexagon) and aqueous (white hexagon) inclusion symbols are filled with vapor bubbles (shaded circles), salt crystals (open squares and polygons), and opaque oxide and sulfide crystals (black shapes). etry data could be obtained from the vapor-rich inclusions because of their small liquid content. PIXE analyses reveal that hypersaline liquidrich inclusions can contain $10.0 \mathrm{wt} \% \mathrm{Cu}$ (table S3). If analytical uncertainties of 20 to $30 \%$ are accounted for, the $\mathrm{Cu}$ concentration may vary by as much as $3.0 \mathrm{wt} \%(11)$. There is as much as $4.5 \mathrm{wt} \% \mathrm{Cu}$ in coexisting vapor-rich inclusions. By contrast, the group 2 inclusions have lower homogenization temperatures $\left(\leq 550^{\circ} \mathrm{C}\right)$ and salinities up to $58 \mathrm{wt} \%$ equivalent $\mathrm{NaCl}$. These brine inclusions have $\mathrm{Cu}$ concentrations below $1.0 \mathrm{wt} \%$, as determined by laser ablation inductively coupled plasma mass spectrometry (8) and our PIXE analyses. However, not all aqueous fluids associated with $\mathrm{P}$ veins contain very high $\mathrm{Cu}$ concentrations. A high-temperature polyphase hypersaline liquid-rich inclusion from a $\mathrm{P}$ vein in a different intrusion with lower $\mathrm{Cu}$ grades contained about 0.5 weight $\% \mathrm{Cu}$ (11) (table S3).

Unusually high $\mathrm{Cu}$ concentrations in fluids trapped in some group 1 inclusions are consistent with these being the most primitive magmatic-hydrothermal fluids found at Bajo de la Alumbrera. The high $\mathrm{Cu}$ concentrations in the fluid dropped during the earliest stages of mineralization (Fig. 3). Fe/Zn parallels the $\mathrm{Fe} / \mathrm{Pb}$ ratio, whereas $\mathrm{Fe} / \mathrm{Cu}$ rises, indicating the removal of $\mathrm{Cu}$ from the fluid. Our results suggest that the absolute $\mathrm{Zn}$ and $\mathrm{Pb}$ concentrations in the group 2 inclusions are slightly higher than those in the group 1 inclusions. Because PIXE analysis of $\mathrm{Cl}$ is sensitive to the thickness of quartz above the inclusion, $\mathrm{Br}$ is used as a proxy for $\mathrm{Cl}$. The $\mathrm{Zn} / \mathrm{Br}$ and $\mathrm{Pb} / \mathrm{Br}$ (and by inference, $\mathrm{Cl}$ ) ratios remain constant (Fig. 3), suggesting that the slight enrichment of $\mathrm{Zn}$ and $\mathrm{Pb}$ probably resulted from separation of the low-salinity vapor from the hypersaline portion of the ore fluid. Appreciable $\mathrm{Cu}$ concentrations in vapor-rich group 1 fluid inclusions imply the formation of volatile $\mathrm{Cu}$ complexes, as found in studies of other porphyry $\mathrm{Cu}$ and $\mathrm{Sn}-\mathrm{W}$ systems $(8$, $15,16)$.

PIXE analyses of vapor and brine inclusions coexisting with homogenized silicate melt inclusions (fig. S2 and table S3) have been used to determine a preliminary brine/vapor partition coefficient for $\mathrm{Cu}$ of $D_{\mathrm{Cu}}$, brine/vapor $=1.5$ to 2 .
Fig. 2. Partly homogenized volatile-rich silicate-melt inclusion in a sulfide-bearing $P$ vein. (A) Optical image; besides a silicate melt portion $(\mathrm{m})$, this inclusion has multiple salt phases ( $s$ ) and vapor bubbles (v). (B) PIXE element distribution maps (11). Legend shown in lower right corner indicates increasing intensity (and thus concentration). Color scale for each image is normalized to its own maximum. The inclusion outline is laid over the $\mathrm{Cl}$ map.
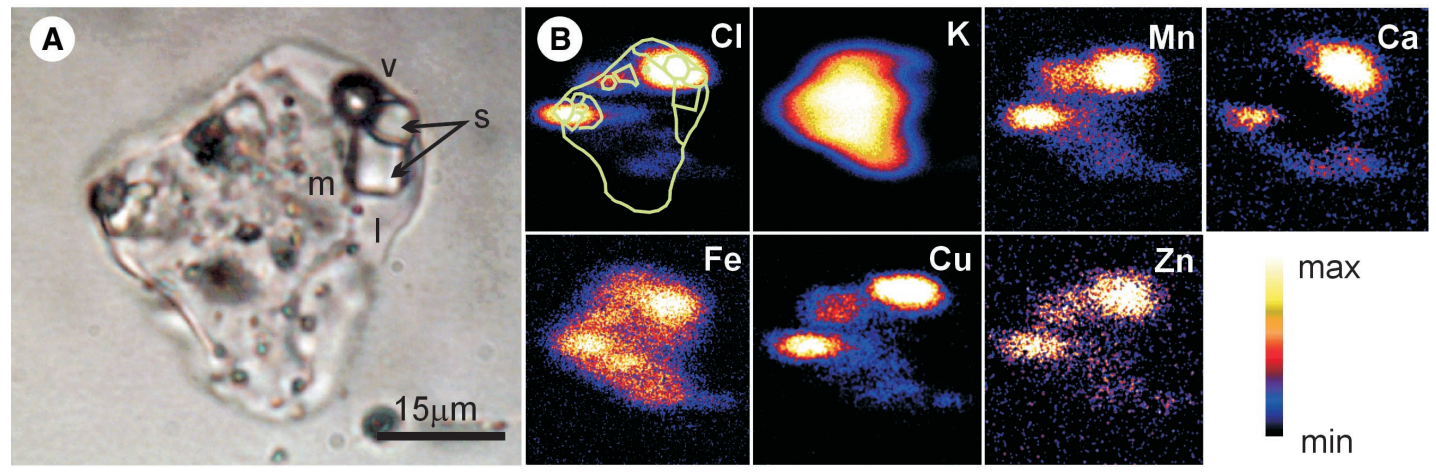
The extremely high $\mathrm{Cu}$ contents found in group 1 inclusions indicate that the brine/melt partition coefficient under the prevailing conditions (temperature, pressure, oxygen fugacity, and salinity) must have been very high unless unreasonably high $\mathrm{Cu}$ concentrations in the magma are assumed. For $\mathrm{Cu}_{\text {melt }}$ of 50 to 200 parts per million (ppm), $D_{\mathrm{Cu}}$, brine/melt equals 500 to 2000 .

On the basis of the calculated salinity and measured temperature of fluid inclusions, combined with experimental data on the $\mathrm{NaCl}-\mathrm{H}_{2} \mathrm{O}$ system, we can estimate the minimum pressure of formation (17). Fluidinclusion assemblages (comprising coexisting low-density vapor and hypersaline fluid) trapped in the bulk of the hydrothermal alteration at Bajo de la Alumbrera have pressures of $\sim 30 \mathrm{MPa}(8)$; however, pressures as high as $100 \mathrm{MPa}$ (equivalent to $\sim 4$ $\mathrm{km}$ depth under lithostatic pressure) have been determined for inclusion assemblages in the $\mathrm{P}$ veins (fig. S3). The contrasting pressure conditions are explained by the early exsolution of group 1 fluids from the magma while the confining carapace was still intact and confining pressure was at a maximum. Subsequent volatile exsolution occurred from the magma after rupturing of the carapace and shattering of the overlying rock column.

Our data from Bajo de la Alumbrera show that the earliest aqueous volatile phase to exsolve from the magma (group 1) separated into two aqueous phases, one comprising about 20 volume \% (an approximation based on the modal abundance of fluid inclusions) of brine containing $\sim 53$ weight $\%$ equivalent $\mathrm{NaCl}$ and $10 \% \mathrm{Cu}$, the other comprising about 80 volume $\%$ of vapor containing $\sim 2.0$ wt $\%$ equivalent $\mathrm{NaCl}$ and $\sim 4.5 \% \mathrm{Cu}$. $\mathrm{Nu}-$ merical models anticipated similar phase proportions, salinities, and metal concentrations from the unmixing of an originally homogeneous aqueous fluid (with salinity $\sim 8.5 \mathrm{wt} \%$ equivalent $\mathrm{NaCl}$ ) exsolved from a subjacent magma at $\sim 100 \mathrm{MPa}$ (18). Furthermore, the observed $\mathrm{Cu}$ concentrations are as high or higher than those previously reported from other inclusion studies $(8,14)$ and experimental modeling of crystallizing melts (3, 18).

We infer that decompression from 100 $\mathrm{MPa}$ to $\sim 30 \mathrm{MPa}$ and cooling from $>745^{\circ}$ to $<550^{\circ} \mathrm{C}$ caused evolution of exsolved fluids (group 1 to group 2) and deposition of $\mathrm{Cu}$ in the earliest evolution of this porphyry ore deposit. Evidence for this comes in part from the PIXE data that reveal between 5 and 10 times higher levels of $\mathrm{Cu}$ occur in some early high-temperature and pressure aqueous phases (group 1) than in the moderate temperature brines (group 2). The data also show near-constant $\mathrm{Zn} / \mathrm{Pb}$, $\mathrm{Zn} / \mathrm{Br}$, and $\mathrm{Pb} / \mathrm{Br}$ (and by inference, metal/ $\mathrm{Cl})$ ratios, from one stage to the next, implying that the earliest fluid (group 1) evolved to the second (group 2). To do that, the evolving magmatic fluid lost a substantial amount of $\mathrm{Cu}$ (up to $10 \mathrm{wt} \% \mathrm{Cu}$ to

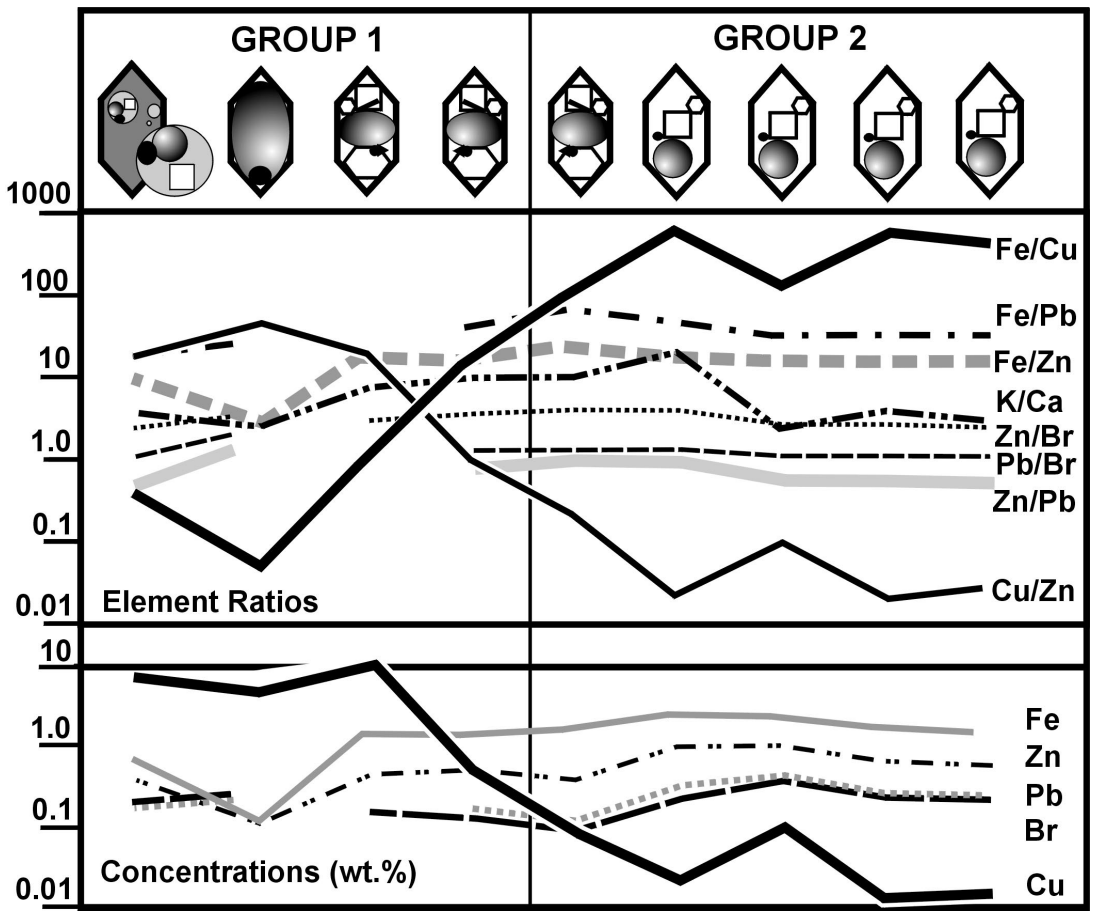

Fig. 3. Element ratios and concentrations from representative liquid compositions from silicatemelt and fluid inclusions from Bajo de la Alumbrera (table S3). The temporal evolution of the system is broadly from left (group 1, primary inclusions) to right (group 2, secondary inclusions). The analyzed silicate-melt inclusion was heated to reveal a single brine globule. below 1 wt $\% \mathrm{Cu}$; also implicit in the observed $\mathrm{Fe} / \mathrm{Cu}$ ratios), which was deposited from the pristine magmatic fluids during or after rupturing of the rock column. Decompression would produce further phase separation of the early-formed magmatic volatile phases, producing new low-density aqueous vapor phases and hypersaline liquids. This aqueous phase immiscibility probably caused additional deposition of $\mathrm{Cu}-\mathrm{Fe}$ sulfides. Halite may also have precipitated $(8)$. Once in a predominantly hydrostatic regime, any change in temperature, $\mathrm{pH}$, and/or oxygen fugacity of the system would have caused $\mathrm{Cu}-\mathrm{Fe}$ sulfides to deposit from the exsolved magmatic fluid $(8,19)$.

References and Notes

1. J. W. Hedenquist, J. B. Lowenstern, Nature 370, 519 (1994).

2. J. B. Lowenstern, G. A. Mahood, M. L. Rivers, S. R. Sutton, Science 252, 1405 (1991).

3. P. A. Candela, P. M. Piccoli, in Magmas, Fluids, and Ore Deposits, vol. 23 of Short Course Series, J. F. H. Thompson, Ed. (Mineralogical Association of Canada, Ottawa, Canada, 1995), pp. 101-127.

4. T. J. Williams, P. A. Candela, P. M. Piccoli, Contrib. Mineral. Petrol. 121, 388 (1995).

5. J. J. Hemley, J. P. Hunt, Econ. Geol. 87, 23 (1992).

6. R. E. Beane, S. R. Titley, 75th Anniv. Vol: Econ. Geol. p. 235 (1981)

7. R. J. Bodnar, in Magmas, Fluids, and Ore Deposits, vol. 23 of Short Course Series, J. F. H. Thompson, Ed. (Mineralogical Association of Canada, Ottawa, Canada, 1995), pp. 139-152.

8. T. Ulrich, D. Günthur, C. A. Heinrich, Econ. Geol. 97, 1889 (2002).

9. L. B. Gustafson, J. P. Hunt, Econ. Geol. 70, 857 (1975).

10. A. C. Harris, V. S. Kamenetsky, N. C. White, in Mineral Exploitation and Sustainable Development: Proceedings of the Seventh Biennial Meeting, Society for Geology Applied to Mineral Deposits, D. G. Eliopoulos et al., Eds. (Millpress, Rotterdam, Netherlands), pp. 275-278.

11. Materials and methods are available as supporting material on Science Online.

12. V. S. Kamenetsky et al., in Melt Inclusions in Volcanic Systems Methods, Applications and Problems, vol. 5 of Developments in Volcanology, E. De Vivo, R. Bodnar, Eds. (Elsevier, Amsterdam, 2003), pp. 65-85.

13. P. Davidson, V. S. Kamenetsky, Econ. Geol. 96, 1921 (2001).

14. V. S. Kamenetsky et al., Chem. Geol. in press.

15. C. A. Heinrich et al., Econ. Geol. 87, 1566 (1992).

16. C. A. Heinrich et al., Geology 27, 755 (1999).

17. R. J. Bodnar et al., Geochim. Cosmochim. Acta 49, 1861 (1985).

18. C. W. Burnham, in Geochemistry of Hydrothermal Ore Deposits, H. L. Barnes, Ed. (Wiley, New York, ed. 3, 1997), pp. 63-123.

19. A. Hezarkhani A. E. Williams-Jones, Econ. Geol. 93, 651 (1998).

20. The Centre for Ore Deposit Research directly funded this work. Samples used in this study were collected during A.C.H.'s research at the University of Queensland, funded by MIM Exploration. We thank D. Steele for valuable assistance with microprobe analyses and D. Cooke, J. Hedenquist, M. Solomon, and three anonymous referees for detailed and helpful reviews of this manuscript.

Supporting Online Material

www.sciencemag.org/cgi/content/full/302/5653/2109/ DC1

Materials and Methods

Figs. S1 to S3

Tables $\mathrm{S} 1$ to $\mathrm{S3}$

31 July 2003; accepted 7 November 2003 


\section{Supporting Online Material}

\section{Material and methods}

Vein material for inclusion analysis was sampled from drillcore and mine workings at the Bajo de la Alumbrera porphyry $\mathrm{Cu}-\mathrm{Au}$ deposit. Representative samples from the earliest alteration stages were selected for analysis. Temporal variations in silicate-melt and fluid inclusions were identified with detailed petrographic observations. Inclusion populations were studied using doubly polished thick sections. Homogenization experiments on silicate-melt and fluid inclusions were performed at 1-atm using a high temperature LINKAM TS1500 heating stage. At high temperatures, the uncertainty in the observed temperature is less than $20^{\circ} \mathrm{C}$. Salinity was calculated from the dissolution temperature of halite and assumes a simple $\mathrm{NaCl}-\mathrm{H}_{2} \mathrm{O}$ system $(\mathrm{S} 1)$. All temperatures are uncorrected for pressure, and therefore lower than the true trapping temperature.

Non-destructive in situ nuclear microscopy by PIXE (Proton Induced X-ray Emission) was used to image the element distribution of remelted silicate-melt inclusions. PIXE technology uses a high-energy proton beam $(3 \mathrm{MeV})$ focused to $1.3 \mu \mathrm{m}$ diameter to penetrate quartz, exciting X-and ?-rays from elements in subsurface silicate-melt or fluid inclusions $(S 2, S 3)$. Samples were prepared as doubly polished thick sections. Inclusions were prepared to within $\sim 10 \mu \mathrm{m}$ of the surface, then photographed and measured (including size and depth) prior to the sample being carbon coated. Element concentration maps were produced by raster scanning the inclusions. Using the Dynamic Analysis method (S2), element concentrations are calculated accounting for the inclusion geometry, depth of the inclusion below the surface and an estimated fluid density. Dynamic Analysis is a standardless technique that calculates element concentration from first principles $(S 4, S 5)$ and corrects for detector solid angle and matrix effects. Individual inclusions were analyzed for up to 20 minutes. A $250 \mu \mathrm{m}$ Be filter was placed in front of the $\mathrm{Si}(\mathrm{Li}) \mathrm{X}$-ray detector to 
reduce the intensity of the background signal. Analytical uncertainty of this technique is estimated at 20-30\%, with higher uncertainty for elements lighter than potassium.

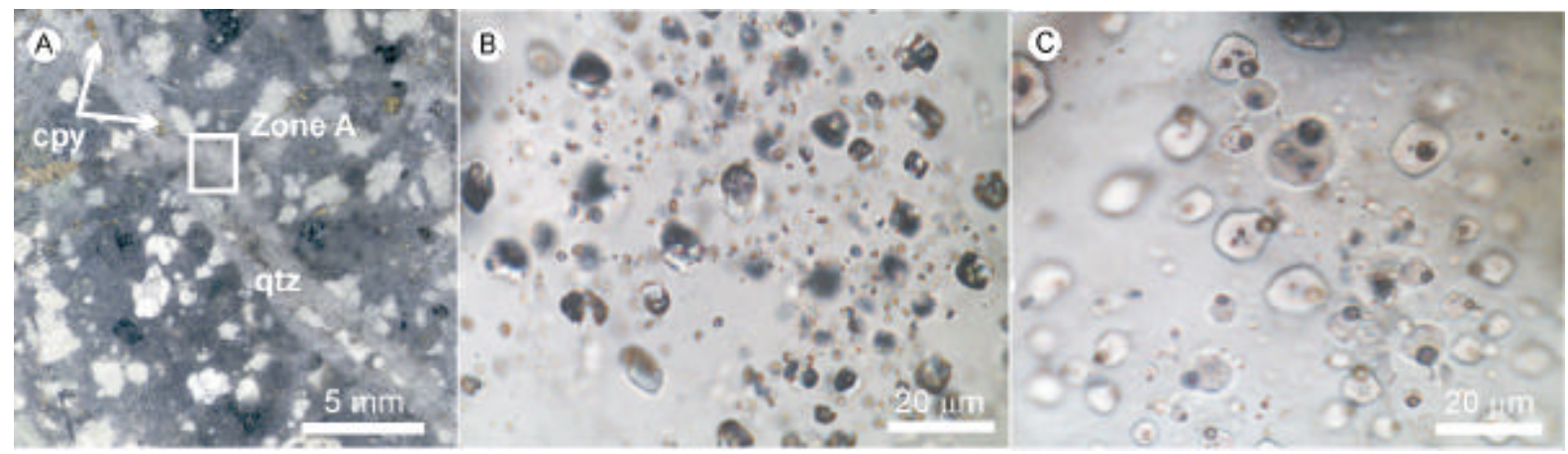

Figure S1. Silicate-melt inclusions in mineralised quartz veins. A.) $\mathrm{P}$ vein that cross cuts potassically-altered dacite at Bajo de la Alumbrera. Chalcopyrite (cpy) is intergrown with vein quartz (qtz). Small intergrowths of K-feldspar, biotite, and hornblende also fill the vein core. The vein margins are ragged and diffuse. B.) Transmitted light photomicrograph of a cluster of silicate-melt inclusions (zone A in previous photo). These darkish grey silicatemelt inclusions are visibly different to brine-rich fluid inclusions typically reported in potassic alteration (8). C.) When heated and quenched after 26 hours at $850^{\circ} \mathrm{C}$ the aluminosilicate content homogenizes to reveal small globules of salt phases with contrasting relief compared to the silicate melt. 
Table S1. Rock sample location and description

\begin{tabular}{|c|c|c|}
\hline Sample & Location & Description \\
\hline 99102 & $\begin{array}{l}\text { Diamond Drill Hole 48.4-54 } \\
124.4 \text { metres }\end{array}$ & $\begin{array}{l}\text { Early P3 Porphyry with relatively pristine magmatic biotite and } \\
\text { plagioclase phenocrysts. Round quartz eyes abundant. Ragged } \\
\text { hornblende phenocrysts also occur. Trace apatite and zircon. Quartz- } \\
\text { feldspar groundmass is altered by biotite } \pm \text { ?illite }- \text { this alteration in part } \\
\text { alters some plagioclase phenocrysts. P veins consist of quartz, with } \\
\text { lesser amounts of K-feldspar } \pm \text { hornblende-biotite-magnetite- } \\
\text { chalcopyrite and pyrite. Veinlets of magnetite also occur, as does } \\
\text { chlorite } \pm \text { ?illite veins. }\end{array}$ \\
\hline 99166 & $\begin{array}{l}\text { Diamond Drill Hole 48.5-54 } \\
139 \text { metres }\end{array}$ & $\begin{array}{l}\text { P2 Porphyry consisting of plagioclase and rare biotite and quartz. } \\
\text { Intense ?illite alteration of plagioclase. Biotite altered by chlorite. } \\
\text { Stockwork of veinlets of quartz-chalcopyrite } \pm \text { biotite-K-feldspar. } \\
\text { Stringers of chalcopyrite very abundant. Rare diffuse P quartz veins. }\end{array}$ \\
\hline 0301 & $\begin{array}{l}\text { Mine Bench } 2450 \mathrm{~m} \text { ASL } \\
-66^{\circ} 36^{\prime} 30.708 \\
-27^{\circ} 19^{\prime} 41.88\end{array}$ & $\begin{array}{l}\text { Biotite-magnetite-quartz } \pm \text { K-feldspar altered ?P2 Porphyry. Intense } \\
\text { pervasive biotite-magnetite alteration obscures phenocrysts and } \\
\text { groundmass. Biotite phenocrysts are recrystallized and the groundmass } \\
\text { feldspars are altered to a mosaic of biotite-quartz-K-feldspar } \pm \text { chlorite- } \\
\text { rutile-apatite. P quartz veins cut this pervasive alteration. The veins are } \\
\text { diffuse with sugary quartz. Chalcopyrite and lesser K-feldspar are } \\
\text { intergrown with the quartz. Chlorite } \pm \text { illite alteration affects the biotite } \\
\text { phenocrysts and less commonly the secondary biotite. }\end{array}$ \\
\hline
\end{tabular}

Table S2. Whole rock geochemistry of mineralized porphyries compared to microprobe chemistry of silicate-melt inclusions found in quartz veins in overprinting hydrothermal alteration.

\begin{tabular}{|c|c|c|c|c|c|c|c|c|c|}
\hline \multirow{3}{*}{$\begin{array}{l}\text { Sample ID } \\
\text { Analyses }\end{array}$} & \multirow{3}{*}{$\begin{array}{c}\text { Early P3* } \\
43- \\
47.1 / 580\end{array}$} & \multirow{3}{*}{$\begin{array}{l}\text { Late P3* } \\
\text { BLA } 48\end{array}$} & \multirow{3}{*}{$\begin{array}{c}\begin{array}{c}\text { Late } \\
\text { Porphyry* }\end{array} \\
\text { BLA } 44\end{array}$} & \multicolumn{2}{|c|}{$\begin{array}{c}\text { Silicate-melt } \\
\text { inclusion in quartz } \\
\text { phenocryst } \dagger\end{array}$} & \multicolumn{2}{|c|}{$\begin{array}{c}\text { Silicate-melt } \\
\text { inclusion in quartz } \\
\text { vein } \dagger \\
\end{array}$} & \multicolumn{2}{|c|}{$\begin{array}{l}\text { Silicate-melt } \\
\text { inclusion in } \\
\text { quartz vein } \dagger\end{array}$} \\
\hline & & & & \multicolumn{2}{|c|}{$99102 \_4 \ddagger$} & \multicolumn{2}{|c|}{ 99166_13 } & \multicolumn{2}{|c|}{ 99166_35 } \\
\hline & & & & \multicolumn{2}{|c|}{$\mathrm{n}=4$} & \multicolumn{2}{|c|}{$\mathrm{n}=4$} & \multicolumn{2}{|c|}{$\mathrm{n}=3$} \\
\hline $\mathrm{SiO}_{2}$ wt.\% & 65.9 & 65.61 & 64.2 & 66.86 & \pm 1.01 & 65.91 & \pm 0.40 & 67.41 & \pm 2.10 \\
\hline $\mathrm{TiO}_{2}$ & 0.56 & 0.64 & 0.66 & $<0.04$ & & $<0.01$ & & $<0.07$ & \\
\hline $\mathrm{Al}_{2} \mathrm{O}_{3}$ & 15.80 & 16.00 & 15.50 & 16.19 & \pm 0.05 & 18.48 & \pm 0.45 & 17.73 & \pm 1.13 \\
\hline $\mathrm{FeO}$ & 2.2 & 4.92 & 2.5 & 0.41 & \pm 0.35 & 0.06 & \pm 0.05 & $<1.08$ & \\
\hline $\mathrm{MnO}$ & 0.1 & 0.11 & 0.1 & $<0.03$ & & $<0.01$ & & $<0.01$ & \\
\hline $\mathrm{MgO}$ & 1.5 & 1.78 & 1.7 & $<0.01$ & & $<0.01$ & & $<0.01$ & \\
\hline $\mathrm{CaO}$ & 3.4 & 3.99 & 2.6 & $<0.03$ & & 0.07 & \pm 0.02 & 0.06 & \pm 0.05 \\
\hline $\mathrm{Na}_{2} \mathrm{O}$ & 3.2 & 2.44 & 3.3 & 2.00 & \pm 0.17 & 2.31 & \pm 0.16 & 2.64 & \pm 0.15 \\
\hline $\mathrm{K}_{2} \mathrm{O}$ & 4.05 & 3.62 & 3.98 & 11.92 & \pm 2.42 & 13.44 & \pm 0.37 & 12.42 & \pm 0.53 \\
\hline $\mathrm{P}_{2} \mathrm{O}_{5}$ & 0.3 & 0.11 & 0.3 & $<0.01$ & & $<0.02$ & & $<0.08$ & \\
\hline
\end{tabular}




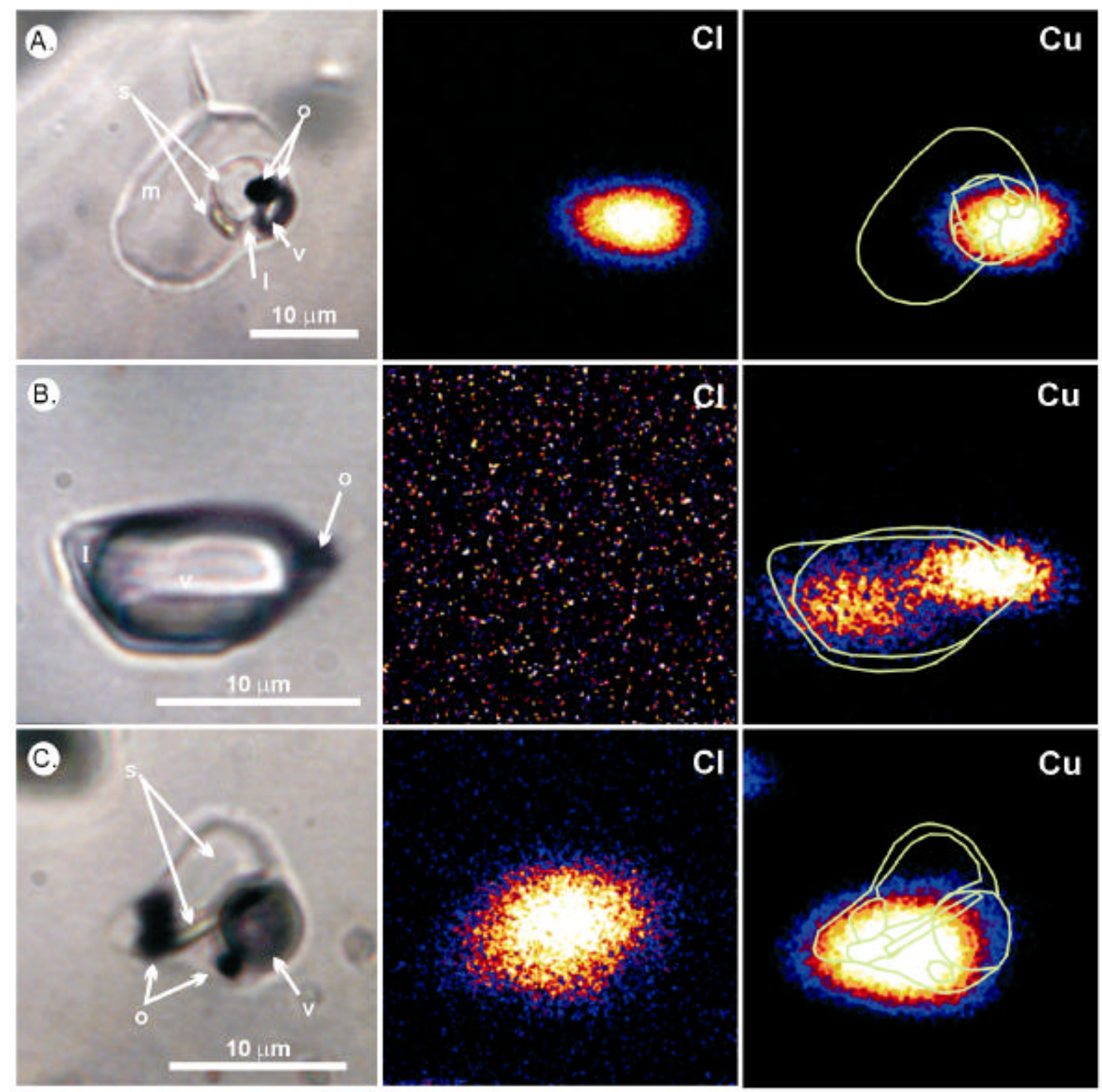

Figure S2. PIXE element distribution maps of primary silicate-melt and fluid inclusions in $\mathrm{P}$ veins. A.) Volatile-rich silicate-melt inclusion in sulfide-bearing $\mathrm{P}$ vein. The original small silicic aggregates homogenized (m) when heated to $850^{\circ} \mathrm{C}$ for 26 hours. Upon quenching a salt-bearing globule formed. Beside salts (s; one of which is halite), there are numerous opaque phases (o), a vapor bubble (v) and a small liquid component (1). To the right of the photomicrograph are the PIXE element distribution maps for $\mathrm{Cl}$ and $\mathrm{Cu}$, respectively. Legend and color scale is the same for Fig 1. The inclusion outline is laid over the $\mathrm{Cu}$ map. B.) Vapor-rich fluid inclusion coexisting with silicate-melt inclusions in $\mathrm{P}$ 
vein. Besides a distinct vapor bubble (v) there is a small liquid component (l) and an opaque phase (o). C.) Polyphase hypersaline liquid-rich inclusion that coexists with silicate-melt inclusions in a $\mathrm{P}$ vein. Besides a liquid component, there is a distinct vapor bubble (v). Moreover, this inclusion is crowded with numerous opaque phases (o) and salts (s), possibly including sulfates.

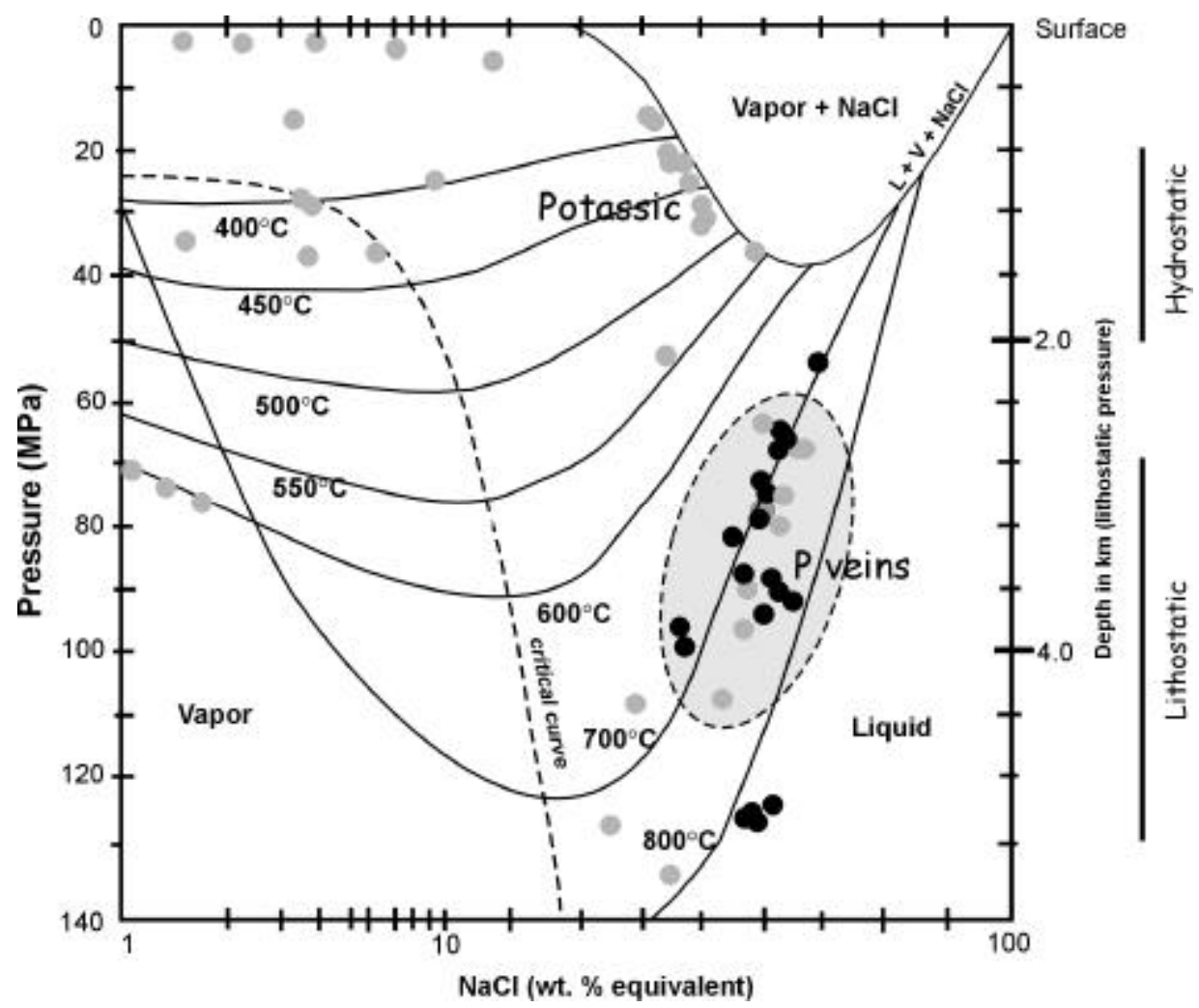

Figure S3. Pressure- $\mathrm{NaCl}$ phase diagram contoured with temperature (modified after Ulrich et al. and references therein; 8). Grey circles represent the data of Ulrich et al. (8). Black circles are aqueous phase equilibria from this study. Primary inclusions found in $\mathrm{P}$ veins have a higher pressure than those in the bulk of the potassic alteration assemblages (8). Independent geologic evidence exists to show that at the time of mineralization the total thickness of rock above the magmatic-hydrothermal system was $\geq 2.5 \mathrm{~km}(S 7)$ - these depths would correspond to lithostatic pressures between 70 and $100 \mathrm{MPa}$. Note that coexisting with some of our primary $\mathrm{P}$ vein hypersaline inclusions are vapor-rich inclusions 
of indeterminate salinity. Based on available aqueous phase equilibria these vapor-rich inclusions should have salinity $<5.0$ wt.\% equivalent $\mathrm{NaCl}(17)$.

\section{Supporting references}

S1. R. J. Bodnar, M. O. Vityk, IMA short course volume (Virginia Polytechnic Institute State Univ. Press, 1994), pp. 117-130.

S2. C. G. Ryan et al., Nucl. Instrum. Methods. B104, 157 (1995).

S3. C. G. Ryan et al., Nucl. Instrum. Methods. B181, 570 (2001).

S4. C. G. Ryan et al., Nucl. Instrum. Methods. B77, 463 (1993).

S5. C. G. Ryan et al., Nucl. Instrum. Methods. B158, 18 (1999).

S6. T. Ulrich, C. A. Heinrich, Econ. Geol. 97, 1865 (2002).

S7. A. C. Harris et al., Mineralium Deposita, in press (DOI: 10.1007/s00126-003-0381-0). 
Table S3. Element concentration data for fluid inclusions from Bajo de la Alumbrera, analyzed by PIXE.

\begin{tabular}{|c|c|c|c|c|c|c|c|c|c|c|c|}
\hline \multirow{3}{*}{$\begin{array}{l}\text { Inclusion Type } \\
\text { Size X (length) } \\
\text { Size Y (width) } \\
\text { Size Z (Thickness) } \\
\text { Midplane } \\
\text { Depth } \\
\text { Assumed density } \\
\text { Sample ID }\end{array}$} & \multicolumn{2}{|c|}{ Magmatic Inclusions } & \multicolumn{3}{|c|}{ Group $1^{*}$} & $\begin{array}{c}\text { Group } 1 \\
\\
25.0\end{array}$ & \multicolumn{5}{|c|}{ Group 2} \\
\hline & $\begin{array}{c}17.0 \\
12.0 \\
12.0 \\
18.0 \\
12.0 \\
2.0 \\
\end{array}$ & $\begin{array}{c}10.0 \\
12.0 \\
7.5 \\
13.5 \\
9.8 \\
1.2 \\
\end{array}$ & $\begin{array}{l}6.5 \\
8.0 \\
7.0 \\
6.0 \\
2.5 \\
1.2 \\
\end{array}$ & $\begin{array}{c}12.8 \\
7.6 \\
3.0 \\
15.0 \\
13.5 \\
0.5 \\
\end{array}$ & $\begin{array}{l}9.3 \\
8.2 \\
5.0 \\
7.5 \\
5.0 \\
1.2 \\
\end{array}$ & $\begin{array}{c}25.0 \\
11.0 \\
11.5 \\
12.0 \\
6.3 \\
1.2 \\
\end{array}$ & $\begin{array}{c}18.0 \\
9.0 \\
6.5 \\
25.5 \\
22.3 \\
1.2 \\
\end{array}$ & $\begin{array}{c}20.6 \\
16.9 \\
9.5 \\
13.5 \\
8.8 \\
1.2 \\
\end{array}$ & $\begin{array}{c}15.3 \\
10.0 \\
4.5 \\
12.0 \\
9.8 \\
1.2 \\
\end{array}$ & $\begin{array}{c}17.8 \\
12.5 \\
9.0 \\
10.5 \\
6.0 \\
1.2 \\
\end{array}$ & $\begin{array}{c}15.8 \\
9.4 \\
9.0 \\
16.5 \\
12.0 \\
1.2 \\
\end{array}$ \\
\hline & $99102 \_4$ & $99102 \_5$ & $0301 \_1$ & 03012 & 0301_3 & 99166_14 & 99166_15 & 99166_17 & 99166_19 & 99166_20 & 99166_21 \\
\hline $\mathrm{Cl}$ (ppm) & DEEP † & 152950 & 249410 & DEEP & 67520 & 74020 & DEEP & 272030 & 282100 & 215560 & DEEP \\
\hline K & 9800 & 41040 & N.D. & 12550 & 26500 & 25710 & 58110 & 91020 & 67570 & 63340 & 29590 \\
\hline $\mathrm{Ca}$ & 1200 & 5770 & 8120 & 4420 & 3530 & 2580 & 5720 & 4490 & 28690 & 16370 & 9870 \\
\hline Ti† & 550 & 1380 & $\mathrm{BDL}$ & 2440 & 440 & 700 & 10780 & 1300 & 1510 & 550 & 730 \\
\hline $\mathrm{Mn}$ & 3400 & 11580 & 8180 & 360 & 11510 & 10650 & 10220 & 22190 & 31600 & 21990 & 16850 \\
\hline $\mathrm{Fe}$ & 8900 & 83630 & 31040 & 2270 & 76700 & 76260 & 89600 & 159670 & 148150 & 94430 & 83360 \\
\hline $\mathrm{Cu}$ & 1300 & 2310 & 73570 & 49430 & 95680 & 5280 & 930 & 240 & 1050 & 150 & 170 \\
\hline $\mathrm{Zn}$ & 1200 & 4700 & 3780 & 1060 & 4800 & 5160 & 4050 & 10130 & 10430 & 6820 & 5900 \\
\hline $\mathrm{Ge}$ & $\mathrm{BDL} \S$ & BDL & $\mathrm{BDL}$ & 930 & BDL & $\mathrm{BDL}$ & 100 & BDL & 150 & $\mathrm{BDL}$ & BDL \\
\hline As & BDL & BDL & 170 & BDL & 140 & BDL & BDL & BDL & BDL & BDL & BDL \\
\hline $\mathrm{Br}$ & 330 & 1720 & 1660 & BDL & 1570 & 1400 & 980 & 2480 & 3890 & 2560 & 2330 \\
\hline $\mathrm{Rb}$ & BDL & 530 & BDL & BDL & 370 & 400 & 520 & 750 & 1030 & 910 & 850 \\
\hline $\mathrm{Sr}$ & 180 & 290 & BDL & BDL & BDL & 190 & BDL & 250 & 710 & 540 & 420 \\
\hline $\mathrm{Ba}$ & 770 & BDL & BDL & BDL & 1360 & BDL & BDL & BDL & BDL & BDL & BDL \\
\hline $\mathrm{Pb}$ & 240 & 1740 & 1600 & BDL & BDL & 1850 & 1300 & 3290 & 4410 & 2890 & 2680 \\
\hline
\end{tabular}

Coexisting inclusions used to calculate brine/melt and brine/vapor partition coefficients of Cu. The melt composition is estimated from typical melt compositions, whereas the brine and vapor components are directly measured. Inclusion $0301 \_1$ is a brine globule in a composite silicate-melt inclusion

$\dagger$ DEEP denotes those inclusions that were too deeply buried beneath the sample surface for $\mathrm{Cl}$ to be quantified

$\ddagger \mathrm{Ti}$ is not likely to be in inclusions, rather it is probably dispersed as rutile inclusions through the quartz host

$\S \mathrm{BDL}=$ below detection limit 